\title{
Graphic text, graphic depiction Genesis 22 and its interpretation on a Louvre miniature plaque ${ }^{1}$
}

\section{C.J.S. Lombaard ${ }^{2}$}

\begin{abstract}
In this contribution in honour of colleague Nico Botha, the habit of debate between him and the author is here continued, namely of discussing Bible text and current interpretation. That model of dialogical engagement is used here to enlarge the understanding, through an artwork in the Louvre, the interpretation possibilities of one of the most disturbing Bible passages, Genesis 22.
\end{abstract}

Keywords: Nico Botha, Bible text and understanding, Genesis 22 and art

\section{A word on colleague Nico Botha}

I met colleague Nico Botha soon after my appointment at UNISA in 2006, although I had known of him previously through his writings. I continue to appreciate his warm welcome then and our frequent, always friendly chats throughout the years. Botha did me the honour of being the first ever to invite me to evaluate a dissertation of a research student of his. He did me an even greater honour of reading me: when inter alia (an expression frequently employed by Botha) in response to his inaugural lecture (Botha, 2008; 2011:133-155), I reacted on the topic of empire and Bible (Lombaard, 2011a:49-65), he returned the favour (Botha, 2016) in a critically-reflective manner which I very much appreciated. Such is the nature of mature academic discussions: that we read sympathetically (i.e. in order to understand as fully as possible) yet critically (i.e. in order to advance our shared understanding within the - overlapping - communities of academia and faith). Botha and I share an interest in the interaction between Bible text and society; Scripture and interpretation (as again demonstrated in Botha 2016). I therefore greatly appreciate the opportunity to publish this contribution here, the more so on a related topic, dedicated to Nico Botha.

1 This contribution is a further development of a paper presented at the 'Religious violence and/or violence in the name of religion' congress of the Association for the Study of Religion in Southern Africa (ASRSA), Department of Religion Studies, University of Johannesburg, 26-28 October 2015.

2 Prof. C.J.S. Lombaard is Research Professor in the Department of Christian Spirituality, Church History and Missiology at the University of South Africa. He can be contacted at ChristoLombaard@gmail. com. 
Genesis 22 namely contains one of the most violent narratives in the Hebrew Bible. Much of its interpretation history is characterised by attempts to deal with precisely its psychologically and religiously disturbing subject matter. In this contribution, the major exegetical approaches, with an emphasis on historical interpretations offered in this regard, in Old Testament research history is taken into brief review. Then follows an analysis of an artistic presentation of the Genesis 22 events as found in a miniature plaque housed in the famous Louvre museum near Paris, France. The telling way in which this artistic presentation is framed in order to deal with its thematics, is discussed, and the section of the Genesis 22 text which it takes into reception most directly, is pointed out.

\section{The depiction and the text}

In the opening section of this contribution, immediately below, the two works which will be brought into discussion with one another in the rest of the contribution, are presented. These are namely a Louvre plaque depicting the Old Testament narrative of the moment in which the ancient Israelite patriarch Abraham is about to kill Isaac, as the execution of an act of child sacrifice following a divine command to do so. The second is the Old Testament text concerned, namely Genesis 22 . The critical Hebrew text edition of the Biblia Hebraica Stuttgartensia (BHS) is reproduced, along with the English translation of it as offered in the New Revised Standard Version. The paragraph indications in that table are simply for the sake of the alignment of the Hebrew and English texts. However, italics have been added in verse 1 and verses 15 to 18 , since this becomes pivotal in the later discussion of this text.

\subsection{The plaque concerned}

The reason for the choice of this artwork is partly a long-standing research programme on Genesis 22, namely on the text itself and on its interpretation history, and partly a chance encounter. In this particular research trajectory, over decades, the following is explored: 1) exegetically, my own understanding of the text, its historical development and the contexts of its origination; 2) the history of the scholarly interpretation of this text, both within mainstream and in more obscure exegetical works; and 3) the history of the extra-scholarly interpretation and usage of this text, in sermons and Bible studies, in literature such as short stories and poetry, in popular media and in various forms of art. The latter now includes, in this contribution, also sculpture, albeit in a miniature format. This particular work depicted above was chanced upon during a visit to the Louvre museum in France, and with a constant vigilance being kept for the sake of such unexpected instances of interpretation of the Genesis 22 text, here too such attentiveness has paid off. 


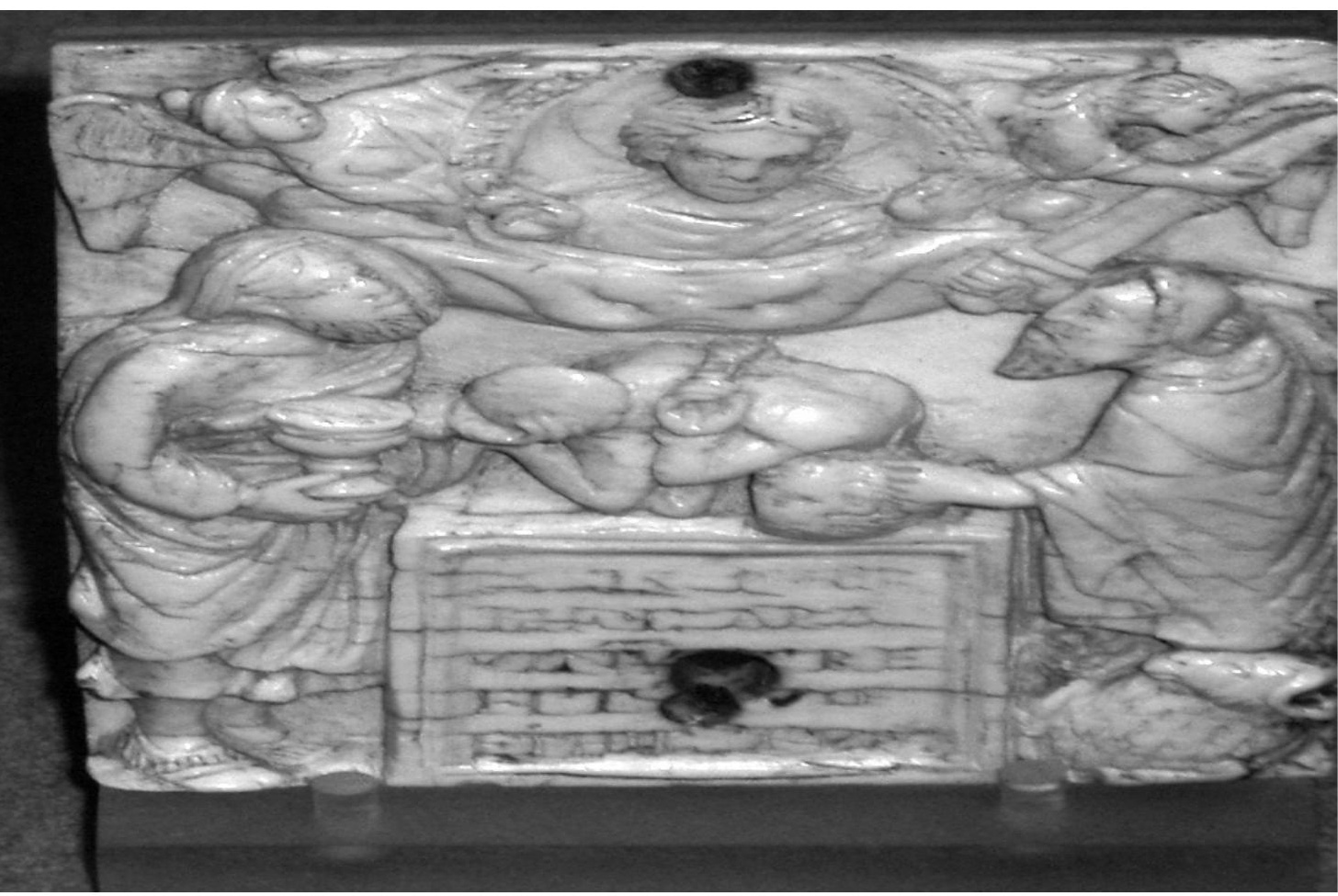

Graphic 1: Mosan plaque of a scene from Genesis 22

Height: $\pm 7 \mathrm{~cm}$; material: enamel (Bardoz, 1996)

Photograph: courtesy of A. Veelmaa (Copyright permission obtained)

To study a work of art requires a different kind of analytical discipline, as is the case with for instance taking cognisance of an exegetical study (which has been done amply for many years as part of this research trajectory on Genesis 22), more akin to noting the nuances in for instance a novel or in the succinct richness of interpretative possibilities of a poem (both of which I have done academically too). In such studies on the extra-scholarly interpretation and usage of Genesis 22, the focus is for the purposes of this research trajectory kept strongly on how that biblical text is portrayed, for the sake of keeping to my primary specialism, with only cursory attention paid to for instance wider interpretation possibilities or placement within the history of art. 


\subsection{The Akedah text ${ }^{3}$ - Genesis 22}

Biblia Hebraica Stuttgartensia

1

2

3

4

5

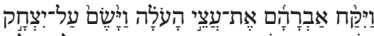

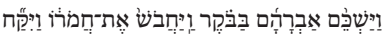

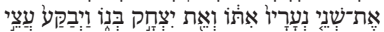

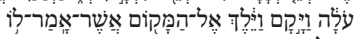

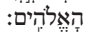

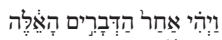

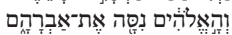

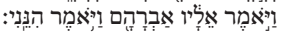

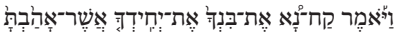

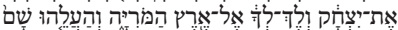

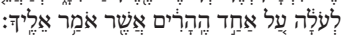

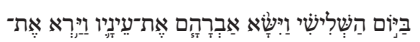

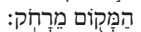

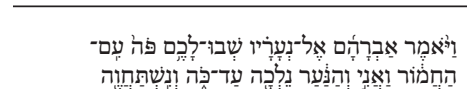

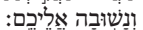

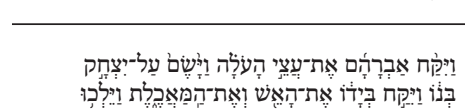

\section{English translation} New Revised Standard Version

(Italics added to verses 1 \& 15-18)
After these things God tested Abraham. He said to him, "Abraham!" And he said, "Here I am."
He said, "Take your son, your only son Isaac, whom you love, and go to the land of Moriah, and offer him there as a burnt offering on one of the mountains that I shall show you."
So Abraham rose early in the morning, saddled his donkey, and took two of his young men with him, and his son Isaac; he cut the wood for the burnt offering, and set out and went to the place in the distance that God had shown him.

On the third day Abraham looked up and saw the place far away.

Then Abraham said to his young men, "Stay here with the donkey; the boy and I will go over there; we will worship, and then we will come back to you."

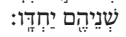

Abraham took the wood of the burnt offering and laid it on his son Isaac, and he himself carried the fire and the knife. So the two of them walked on together.

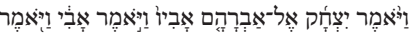

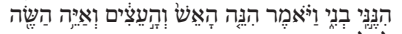

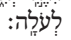

8

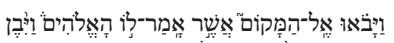

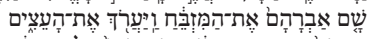

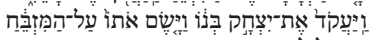

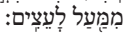

Isaac said to his father Abraham, "Father!" And he said, "Here I am, my son." He said, "The fire and the wood are here, but where is the lamb for a burnt offering?"

Abraham said, "God himself will provide the lamb for a burnt offering, my son." So the two of them walked on together.

When they came to the place that God had shown him, Abraham built an altar there and laid the wood in order. He bound his son Isaac, and laid him on the altar, on top of the wood.

3 "Akedah" is the Hebrew term meaning "binding"; by implication: "the binding of Isaac." It is the technical term used in much of Old Testament scholarship to refer to this chapter, usually with verses 20 to 24 left out of consideration, though this is seldom pointed out. 
10

11

2

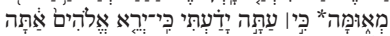

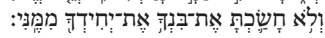

Then Abraham reached out his hand and took the knife to killa his son.

But the angel of the LORD called to him from heaven, and said, "Abraham, Abraham!" And he said, "Here I am."

He said, "Do not lay your hand on the boy or do anything to him; for now I know that you fear God, since you have not withheld your son, your only son, from me."

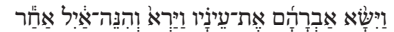

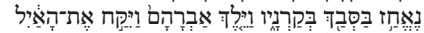

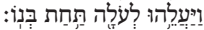

And Abraham looked up and saw a ram, caught in a thicket by its horns. Abraham went and took the ram and offered it up as a burnt offering instead of his son.

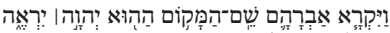

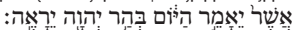

15

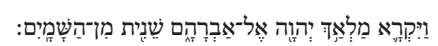

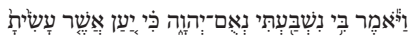

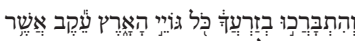

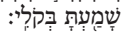

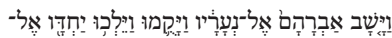

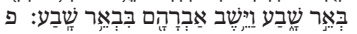

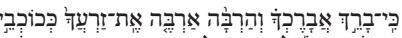

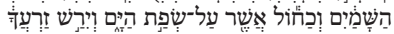

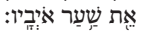

20

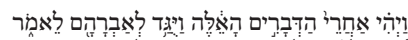

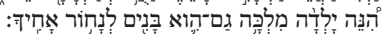

21

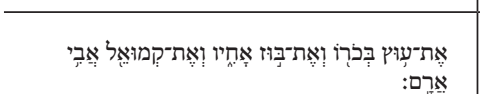

So Abraham called that place "The LORD will provide"; as it is said to this day, "On the mount of the LORD it shall be provided."

The angel of the Lord called to Abraham a second time from heaven,

and said, "By myself I have sworn, says the Lord: Because you have done this, and have not withheld your son, your only son,

I will indeed bless you, and I will make your offspring as numerous as the stars of heaven and as the sand that is on the seashore. And your offspring shall possess the gate of their enemies,

and by your offspring shall all the nations of the earth gain blessing for themselves, because you have obeyed my voice."

So Abraham returned to his young men, and they arose and went together to Beer-sheba; and Abraham lived at Beer-sheba.

Now after these things it was told Abraham, "Milcah also has borne children, to your brother Nahor:

Uz the firstborn, Buz his brother, Kemuel the father of Aram,

Chesed, Hazo, Pildash, Jidlaph, and Bethuel." 


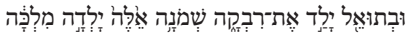

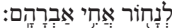

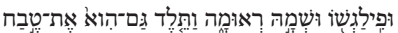

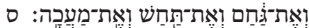

Bethuel became the father of Rebekah. These eight

Milcah bore to Nahor, Abraham's brother.

Moreover, his concubine, whose name was Reumah, bore Tebah, Gaham, Tahash, and Maacah.

\section{A-historical and historical explanations of the akedah narrative}

The Genesis 22:1-19 text is one of the texts most often referred to when violence in the Jewish and Christian Bible is discussed. These verses, along with for instance Deuteronomy $13^{4}$ and the closing verses of Psalm 137,5 share the characteristic that God is directly implicated in the proposed violence. Genesis 22 has, however, the additional particularity that God is cast as the instigator of such a deed:

${ }^{2} \mathrm{He}$ [= God] said, "Take your son, your only son Isaac, whom you love, and go to the land of Moriah, and offer him there as a burnt-offering on one of the mountains that I shall show you."

Moreover, God is in the narrative made a party to the deliberate deception of the unwitting victim Isaac:

${ }^{7}$ Isaac said to his father Abraham, "Father!" And he said, "Here I am, my son." He [= Isaac] said, "The fire and the wood are here, but where is the lamb for a

4 This Deuteronomy chapter includes, for instance, these verses:

${ }^{6}$ If anyone secretly entices you-even if it is your brother, your father's son or* your mother's son, or your own son or daughter, or the wife you embrace, or your most intimate friend-saying, 'Let us go and worship other gods', whom neither you nor your ancestors have known, ${ }^{7}$ any of the gods of the peoples that are around you, whether near you or far away from you, from one end of the earth to the other, ${ }^{8}$ you must not yield to or heed any such persons. Show them no pity or compassion and do not shield them. ${ }^{9}$ But you shall surely kill them; your own hand shall be first against them to execute them, and afterwards the hand of all the people. ${ }^{10}$ Stone them to death for trying to turn you away from the Lord your God, who brought you out of the land of Egypt, out of the house of slavery. ${ }^{11}$ Then all Israel shall hear and be afraid, and never again do any such wickedness.

5 The closing verses of Psalm 137 reads:

${ }^{7}$ Remember, 0 Lord, against the Edomites

the day of Jerusalem's fall,

how they said, 'Tear it down! Tear it down!

Down to its foundations!'

${ }^{8} 0$ daughter Babylon, you devastator!

Happy shall they be who pay you back

what you have done to us!

${ }^{9} \mathrm{Happy}$ shall they be who take your little ones

and dash them against the rock! 
burnt-offering?" ${ }^{8}$ Abraham said, "God himself will provide the lamb for a burntoffering, my son."”

As to the last words in this text, readers who are familiar with this account already know beforehand that it will, within the narrative, turn out to have been a predictive phrase. Within the account itself, though, the intent is to mislead Isaac, namely by calling on God's providence in order to put Isaac's mind at ease.

Such instances as these two just pointed out - God commanding murder, and God being implicated in a lie by the progenitor of the believers in three major world religions - are quite naturally seized upon when the existence of God, the legitimacy of religion and the possible authority of the (Hebrew) Bible as a holy text are critically discussed.

Historical explanations, first, for the occurrence of this text in the Bible and, second, for certain aspects of the phenomenology of the text, tend to offer greater possibilities than other (e.g. literary or philosophical) explanations, in order to come to a more valid understanding of this text within its own plausibly reconstructible contexts of origination. These possibilities have been reviewed in my earlier publications on this matter, e.g.:

- "The Akedah: an overview of some historical interpretations" (Lombaard, 2011b:259-267).

- "Problems of narratological analyses of Genesis 22:1-19" (Lombaard, 2008a:49-62).

The implication of such historical exegeses is usually that, should this ancient (or perhaps: original) historical placement and therefore meaning become clear, the violent nature of the text would become understandable (e.g. Lombaard, 2019:113-123). Hence, an apologetic purpose, whether intended or not, would usually then have been served.

Interestingly, while in the academic world the latter dynamic of historical proposals is at least tacitly understood, in broader religious circles (synagogue, church), the strong preference has always been for non-historical explanations. This, mostly, because the biblical texts are read in a naively-historical way, as if they would relate history first hand (Lombaard, 2014:205-225). This means that, immediately, a lofty purpose with this disturbing Genesis 22 account has to be sought, for apologetic reasons. Such non-historical or naively-historical explanations are without significant exception found in the idea of a divine test set to Abraham, the forebear of all believers within the Abrahamic religious traditions. This divine test which Abraham passes, is then indicated as something to be emulated by all believers - a faith lesson, as it were. 
This same "lesson" reflexively concluded to in non-scholarly approaches to the Genesis 22 account, is therefore also found among scholars who follow a-historical methodologies, such as narratological exegesis, in which the text is read according to literary criteria of interpretation (such as characterisation, plot, tension and denouement). Almost without fail, the conclusion reached by this kind of reading of the text, is that "God tests Abraham" (the exact terminology of e.g. Kruger, 1991:187-200; a notable recent alternative is however offered in Fischer, 2012:303). This kind of ahistorical approach is highly unsatisfactory if the intent with the exegesis is to explain the meaning of the text to various modern readerships (Lombaard, 2008a:49-62). Simply retelling the compact Genesis 22 narrative in a roundabout way - as for instance is the case when having to explain a poorly understood joke - namely does not solve the disturbing morality implied by a God who orders filicide, nor of an ancestor of three faiths outrightly breaking the ninth commandment. Pretenses to the contrary (i.e. that these questions are solved with e.g. narrative methodology) by theologians are disingenuous, leaving thoughtful questions asked by earnest lay believers - and, frankly, by sincere theologians themselves too - merely dangling.

Though by no means the starting point of historical understandings of this text, the title of Moberly's article of some three decades ago (1988:302-323), certainly summarises earlier scholarship accurately, namely on where historical understandings on this text ought to begin: "The earliest commentary on the Akedah." His point is namely that the stylistically and theologically fully obvious insertion into Genesis 22 of verses 15-18, and of its summary, verse $1 \mathrm{~b}-$ " (and / that) God tested Abraham" (Lombaard, 2017) - constitutes the first reinterpretation of the Genesis 22:1-19 account. Inside the final text as we now have it, the earlier text is already reinterpreted. Without these editorial additions, in other words: when the text is read with these insertions omitted, the chapter has a different hue, telling the ignoble story of a patriarch who was about to perform child sacrifice. Clearly, soon - within perhaps three decades after its creation - the discomfit this story calls forth was plastered over by what may be termed the obedience insertions. This editorial work on the older narrative was however awkwardly done, since the moral difficulties are not thereby solved; to the contrary, they are in fact heightened, dramatically, by now implicating the God.

The poor quality of this theological dressing, attempted by means of verses 1518 \& 1b, had always been visible clearly enough to historically-oriented scholars. For a moment here to intermingle some allusions to well-known fables: the cloak of respectability had been poorly hung by the Genesis 22 editor; the text's new clothes in reality reveal all.

The main historical explanations for the neatly trimmed text (Lombaard, 2011b:259-267, summarised in more popular format in Lombaard, 2013:34-36), 
that is: without the verse 15-18 \& $1 \mathrm{~b}$ additions (except in the case of White's contribution below), include that the Akedah narrative of Genesis 22:

- Polemicises against the possibility of child sacrifice in ancient Israel (Boehm, 2004:145 on, classically, Westermann, 1987:363 and especially Gunkel, 1910:240-243), rather than legitimising such a religious act, as is often popularly assumed;

- Memorialises ancient initiation rites within Israel (White, 1979:1-30; White, 1991:187-203);

- Philosophically prepares the way, through a relatively unrefined treatment of the theodicy issue, namely as antecedent text, for the more mature dealing with the problem of suffering by the book of Job (Veijola, 2002:127-144);

- Reflects tensions on social and geographical matters between the post-exilic carriers of the respective patriarchal traditions, in which the Abraham groupings here put paid to a diminutive Isaacite group's claims to an own theological and geographical identity (Lombaard, 2008b:907-919).

These possibilities summarise the full spectrum of classic and up to date exegetical interpretation possibilities related to the Genesis 22 text $^{6}$. Whichever (combination) of these and other historical explanations are opted for, in all cases they advance beyond the possibilities offered by a-historical explanations in understanding the coming-into-being of this disturbing account in the Bible. Importantly, none of these historical explanations accept this chapter as a (biblical / theological / religious) legitimation of child sacrifice in particular, or of (biblical / theological / religious mandated) violence in general. To be sure, these historical interpretative options by no means end the discussion on the violent nature of the Genesis 22 text; they do however place that discussion on a different, better-informed niveau than a-historical understandings tend to enable.

Given this wider framework of interpretative possibilities summarised above, the way in which Genesis 22 is depicted in art can now be studied in greater depth. This, not with the above scholarly understandings meant as a kind of measuring rod against which to evaluate the validity of an artistic presentation. Rather what is meant here, drawing on the benefit of a more informed exegetical stance, is analysis in the spirit of gaining insight dialogically (as my colleague Botha and I shape each other's views), with the world of art here as discussion partner on interpretative possibilities.

6 To review here the research history on the occurrence of violence, on how that has been variously related to religion, and on how this again has then been related to the biblical or, more specifically, the Old Testament texts, is of course impossible here; that would require an encyclopaedic work, rather than an article. 


\section{The plaque: Placated meaning?}

Like many scenes from mythical, legendary and religious texts, the Genesis 22 account of the almost-slaying of Isaac by Abraham, and that on the instruction of God, has gripped artistic minds throughout the ages, becoming the inspiration for depictions in artworks of various kinds. These range from North African clay shards from the 5th century (Herrmann \& van den Hoek, 2003:34) to modern African church music (King, 2006:61-68) to internet-based cartoons ("Yahweh's amazing test [Abraham, Genesis 22]" - http://unchainthetree.com/genesis-22/); from thoroughly evangelistic messages in sermon content presented in journalistic format (Johnson, 2014) to philosophical short stories (Kierkegaard, 1843); from famous paintings such as Caravaggio's "The Sacrifice of Isaac" (1598 \& 1603) and Rembrandt's "The Angel Prevents the Sacrifice of Isaac" (1635; e.g. Shankman, 2010:1-22) to sketches for Bible translations (e.g. Gustave Doré's "The trial of Abraham's faith"; Doré, 1974:16) to the miniature artwork discussed here.

Although the specific content of this work of art is of greater interest for the purposes of this contribution here, the formal aspects of this miniature (Bardoz, 1996; drawing on Durand, 1996:48-53) are in themselves already telling. The diminutive representation of such a large thematics may seem quite remarkable at first glance, but within the genre of the Mosan crosses, the artwork that flourished around the 12th to 14th century Flanders Meuse valley region (of which genre this piece, depicted in 2.1 above, is representative), it is fully in step (Balace, 2012:3744 , and substantively, Balace, 2009). In a time of intellectual and economic growth, religious art that drew anew on ancient topics was at that time more frequently commissioned (Musée de Cluny, 2013:5-6). This meant, concretely, that on Mosan crosses, important biblical figures were often found (Gómez-Moreno, 1968:263).

From this particular Mosan cross, a number of plaques, now disassembled, remain in the Louvre: of Christ, of the evangelists Mark and Luke, of the historic 7th century encounter of emperors Heraclius and Chosroes (Musée de Cluny, 2013:26-27) and of Old Testament scenes - the latter all apparently meant as prefigurations of the death of Jesus (the references in Balace, 2009:143, 145, 373 to some related artistic interpretations of Isaac used prefiguratively). It is amongst these that our plaque counts, as an enamel work that would be mounted on the back of the metal cross - a construction that is not unusual in Mosan artwork (Gómez-Moreno, 1968:265). The holes we see in the photograph above, bored through the altar at the bottom of the representation and just above the head of the angel, show how this plaque had been fastened to the iron cross.

The contents of the plaque depict the dramatic moment just as Abraham is about to slay Isaac - Genesis 22:11-12. The substitute ram - Genesis 22:13 - is pictured under Abraham's foot. The intensity of the moment is captured, apart from the 
raised hand with sword, also by Abraham's left hand, which holds onto Isaac in such a way that the latter's neck is fully vulnerable to a cutting blade. Interestingly, decapitation seems to be implied here, since the slaughter of animals is most often undertaken across the soft flesh on the other side of the neck.

Isaac is the picture of powerlessness, even innocence: his bodily features are those of a young child, and his posture, except for the fact that he is raised on his knees in order for his neck to be exposed, is fetal. His arms tied behind his back serve to stress his vulnerability. Above Isaac, in a stylised heavenly bow, yet very close, is the angel of the Lord and - extra-biblically - two cherubs. It is the one of the cherubs who, poignantly, prevents the swoop of the sword in this depiction, whilst the other seems to hold open a window to heaven, through which the apparition, or perhaps revelation if meant more symbolically, undertakes its saving work. Also from outside he Bible is a figure to the left of the plaque, holding in his hands the elements of Holy Communion: a wine goblet and bread. The latter figure has sense when the slaughter of Isaac is imagined within a relationship to the death of Christ, which given the already mentioned prefigurative role that Old Testament motifs play in this Mosan cross, seems to be a plausible deduction.

The altar has Latin lettering inscribed on it, which is more or less illegible. The word pierced by the mounting hole is probably "matre," mother, in an ablative sense. Moreover, the angel of the Lord, the centre top figure, has distinctly female features. Precisely what is intended by these two features is not possible to fathom, but feminist interpretations of this text that point to the surprising absence of a female figure in the Genesis 22 account, may find herein some fruitfully interpretative parallels related to these two characteristics.

That Genesis 22 would be related to the death of Jesus, is nothing new - it starts already in the New Testament, most directly with Hebrews 11:17 (more broadly, Bekker \& Nortjé, 1995:454-464). However, the way in which it is done in this plaque is unique, with both the figure holding the elements of the communion and the presence of other plaques inferring Jesus' death from Old Testament scenes making that association here clear.

Interestingly, though, the scene does not depict the heroic Abraham of verses 1518 ; this is the Abraham of verse 10 , willingly bringing human sacrifice. The violence of the scene is here not softened by - again Moberly's title (1988:302-323) - "(t) he earliest commentary on the Akedah," verses 15-18. Rather, sense is made here of this almost-murder by the thematically parallel event in Christian theology where Jesus is sacrificed on the cross by his Father. The violence of Genesis 22 is not softened in this plaque (with decapitation implied, possibly rather the opposite), but subsumed under a more significantly violent event, with the implied understanding that the latter is something positive. 
The symbolic meaning of the crucifixion thus enfolds the filicide thematics here. Clearly, as is also the case with the Genesis 22 additions, in this broader theology too the ethics of violence is left largely unconsidered. At most, an ethics of peace, namely for all and for eternity, is something postponed, an imagined or hoped-for future event, not directly or explicitly considered here. However, given the social context of origination of this plaque and the Mosan cross with which it is associated, such an end-times peace would probably have been associatively present in the mind of the plaque artist.

\section{Journey of understanding}

As stated in the opening paragraphs on the nature of academic discussions: their purpose is "that we read sympathetically (i.e. in order to understand as fully as possible) yet critically (i.e. in order to advance our shared understanding within the - overlapping - communities of academia and faith)." This we see as much in interacting with current discussion partners as in analysing ancient biblical texts; the latter, in reconstructing its possible meaning/s in its ancient context/s, and in research history, and in other, for instance artistic, acts of reception. The Mosan plaque analysed above demonstrates how a new, that is: non-standard re-interpretation, perhaps a re-imagination, of one of the most disturbing texts from the old Testament is offered. Such an interpretative vision is clearly related to faith - in the general sense, that these works of art often depicted religious thematics; in the social sense, that this particular plaque had something to say within its contemporary community of faith; and in the personal sense, that, in various ways, the artist concerned interacted with the Genesis 22 text itself: with its possible meanings available within his social milieu, and then as creative mediator contributing to the historical interpretative trajectory (Wirkungsgeschichte) of this text. Although this plaque does not assist us in elucidating the contextual-historical meaning/s of Genesis 22 within its processes of origination, it enriched its own interpretative community and those of us in its wake by adding another possibility of understanding. This, in seeking to come to terms with what the Bible text expressed "then," within its ancient world, and "now," via its Wirkungsgeschichte, within our world/s.

It is a pleasure to have colleague Nico Botha as a contributor along such journeys of broadening understanding...

\section{Bibliography}

Balace, S. 2012. L'art mosan versus l'art de la France du Nord: Essai historiographique, in Descatoire, C. \& Gil, M. (dir.) Une renaissance. L'art entre Flandre et Champagne, 1150-1250. Paris: Réunion des musées nationaux - Grand Palais, 37-44.

Balace, S. 2009. Historiographie de l'art mosan (Doctorat en histoire, art et archéologie: Département des sciences historiques). Liège: Université de Liège. 
Bardoz, M.C. 1996. Four plaques from the same cross: Christ Blessing - Saint Mark, and The Sacrifice of Abraham - Cherub, and Heraclius and Chosroes - Saint Luke, and Abraham and Melchisedech. Available from: www.louvre.fr/en/oeuvre-notices/fourplaques-same-cross-christ-blessing-saint-mark-and-sacrifice-abraham-cherub-and-h [last accessed, 1 November 2019].

Bekker, C.J., \& Nortjé, S.J. 1995. Die gebruik van die offer van Isak as 'n motief vir die verkondiging van Jesus as die lydende Christus. HTS Theological Studies, 51(2), 454-464.

Boehm, 0. 2004. Child sacrifice, ethical responsibility and the existence of the people of Israel. Vetus Testamentum, 54(2), 145-156.

Botha, N.A. 2008. Can Christianity be saved from empire? Some theological responses towards a prognosis. Inaugural lecture: University of South Africa / Department of Christian Spirituality, Church History and Missiology departmental seminar, 11 February 2009.

Botha, N. 2011. Living at the edge of empire: Can Christianity prevail and be effective? A theological response to the historical struggle between empire and Christianity. Studia Historiae Ecclesiasticae 37, 133-155.

Botha, N. 2016. Bible and empire: Between ambiguity, accommodation and resistance. Paper presented at the Department of Biblical and Ancient Studies Unisa seminar, Izak Spangenberg @ 65: Paradigm Shifts in Ancient Israel, Religion and Theology Studies in South Africa, 26-27 October 2016, University of South Africa.

Doré, G. 1974. The Doré Bible illustrations. New York: Dover Publications.

Durand, J. 1996. Au département des Objets d'art du Louvre une plaque centrale de croix mosane du XIIe siècle représentant le Christ bénissant. La Revue du Louvre 5(6), 48-53.

Fischer, S. 2012. Von der historisch-kritischen Methode zu aktuellen Ansätzen alttestamentlicher Exegese. Am Beispiel der Opferung Isaaks (Genesis 22). Amt und Gemeinde 63(1), 293-304.

Gómez-Moreno, C. 1968. The mystery of the eight evangelists. New York: The Metropolitan Museum of Art Bulletin 26(6), 263-268.

Gunkel, H. 1910. Genesis (Göttinger Handkommentar zum Alten Testament). Göttingen: Vandenhoeck \& Ruprecht.

Herrmann, J.J., \& van den Hoek, A. 2003. Light from the age of Augustine: Late antique ceramics from North Africa (Tunisia) (2nd ed.). Austin, TX: Institute for the Study of Antiquity and Christian Origins - University of Texas.

Johnson, S.I. 2014. Genesis 22:1-14. Ghana Christian Post, 12 July 2014. Available from: http://ghanachristianpost.com/?p=3866 [last accessed, 1 November 2017].

Kierkegaard, S. (= de Silentio, J.) 1843. Frygt og Bœeven. Dialektisk Lyrik. S.l.: s.n.

King, R. 2006. Abraham goes Senufo: Communicating the Scriptures through song, in: Fortunato, F. (ed). All the world is singing: glorifying god through the worship music of the nations. Tyrone, GA: Authentic Publishing, 61-68.

Kruger, H.A.J. 1991. God tests Abraham: The command to sacrifice Isaac. Ned. Geref. Teologiese Tydskrif 32(2), 187-200. 
Lombaard, C 2008a. Problems of narratological analyses of Genesis 22:1-19, in Augustin, M. \& Niemann, H.M. (eds). 2008. Thinking towards new horizons. Collected communications to the XIXth congress of the International Organization for the Study of the Old Testament, Ljubljana 2007 (Beiträge zur Erforschung des Alten Testaments und des Antiken Judentums 55). Bern: Peter Lang, 49-62.

Lombaard, C. 2008b. Isaac multiplex: Genesis 22 in a new historical representation. HTS Theological Studies / HTS Teologiese Studies 64(2), 907-919.

Lombaard, C. 2011a. No empire, no Bible? Aspects of the relationship between biblical texts and current anti-empire views. Studia Historiae Ecclesiasticae XXXVII, 49-65.

Lombaard, C. 2011b. The Akedah: An overview of some historical interpretations. Ekklesiastikos Pharos 93 (N.S. 22), 259-267.

Lombaard, C. 2013. Five historical explanations for Genesis 22 and its inclusion in the Scripture, in Roncace, M. \& Weaver, J. (eds). Global perspectives on the Bible. London: Pearson, 34-36.

Lombaard, C. 2014. Getting texts to talk. A critical analysis of attempts at eliciting contemporary messages from ancient holy books as exercises in religious communication. Ned. Geref. Teologiese Tydskrif 55(1), 205-225.

Lombaard, C. 2019. Testing tales: Genesis 22 and Daniel 3 and 6, in: Gillmayr-Bucher, S. \& Häusl, M. (eds). Prayers and the Construction of Israelite identity (Ancient Israel and its literature 35). Atlanta: SBL Press, 113-123.

Moberly, R.W.L. 1988. The earliest commentary on the Akedah. Vetus Testamentum 38(3), 302-323.

Musée de Cluny. 2013. Une Renaissance. L'art entre Flandre et Champagne. 1150-1250. Paris: Editions de la Réunion des musées nationaux.

Shankman, S. 2010. Other others. Levinas, literature, transcultural studies. New York: SUNY Press.

Veijola, T. 2002. Abraham und Hiob. Das literarische und theologische Verhältnis von Gen 22 und der Hiob-Novelle, in: Bultmann, C., Dietrich, W. \& Levin, C. (Hrsg.) Vergegenwärtigung des Alten Testaments. Beiträge zur biblische Hermeneutik (Festschrift für Rudolf Smend zum 70. Geburtstag). Göttingen: Vandenhoeck \& Ruprecht, 127-144.

Westermann, C. 1987. Genesis 12-36. Grand Rapids: William B Eerdmans.

White, H.C. 1979. The initiation legend of Isaac. Zeitschrift für die alttestamentliche Wissenschaft $91,1-30$.

White, H.C. 1991. "Where is the lamb for the burnt offering?" Genesis 22, in: White, H.C. (ed.) Narration and discourse in the book of Genesis. Cambridge: Cambridge University Press, 187-203.

\section{Footnotes}

a Verse 10 - Or to slaughter.

b Verse $14 a$ - Or will see; Hebrew traditionally transliterated Jehovah Jireh [Lombaard emendation: Adonai Jireh / Shemah Jireh].

c Verse $14 \mathrm{~b}$ - Or he shall be seen. 